\title{
Microbiological, physical and chemical properties of joruk (fermented fish product) with different levels of salt concentration
}

\author{
DYAH KOESOEMAWARDANI ${ }^{1, \boldsymbol{v}}$, LULU ULYA AFIFAH ${ }^{1}$, NOVITA HERDIANA ${ }^{1}$, A.S. SUHARYONO ${ }^{1}$, \\ ESA GHANIM FADHALLAH ${ }^{1}$, MAHRUS ALI ${ }^{2}$ \\ ${ }^{1}$ Department of Agricultural Product Technology, Faculty of Agriculture, Universitas Lampung. Jl. Prof. Dr. Soemantri Brojonegoro No. 1, Bandar \\ Lampung 35145, Lampung, Indonesia. Tel.: +62-721-701609. Fax.: +62-721-702767, `email: dyah.koesoemawardani@ @p.unila.ac.id \\ ${ }^{2}$ Department of Fisheries and Marine Sciences, Faculty of Agriculture, Universitas Lampung. Jl. Prof. Dr. Soemantri Brojonegoro No. 1, Bandar \\ Lampung 35145, Lampung, Indonesia
}

Manuscript received: 18 November 2020. Revision accepted: 14 December 2020.

\begin{abstract}
Koesoemawardani D. Afifah LU, Herdiana N, Suharyo AS, Fadhallah EG, Ali M. 2021. Microbiological, physical, and chemical properties of joruk (fermented fish product) with different levels of salt concentration. Biodiversitas 22: 132-136. Joruk is a fermented fish product originated in Ogan Komering Ulu Timur, South Sumatra, Indonesia. The aim of this study was to determine the effect of salt on the microbiological, physical and chemical properties of joruk. This research was arranged in a Randomized Complete Block Design (RCBD), with treatment of salt concentrations at 5\%, 10\%, 15\%, 20\%, 25\%, and 30\% (w/w). The follow-up test used the Least Significance Difference (LSD) at 5\%. The result of this study showed that the addition of $10 \%$ salt produced the best joruk with the best microbiological and chemical properties as follows: total LAB of $8.75 \log \mathrm{cfu} / \mathrm{g}$, total microbes of $13.25 \mathrm{log} \mathrm{cfu} / \mathrm{g}$, and total mold of $4.27 \mathrm{log} \mathrm{cfu} / \mathrm{g}, \mathrm{pH}$ of 5.85, total lactic acid of $2.97 \%$, Total Volatile Base (TVB) of $153.05 \mathrm{mgN} / 100 \mathrm{~g}$, and water content of $59.33 \%$. Based on this study, it is concluded that the addition of salt at different concentrations significantly affects the $\mathrm{pH}$, total lactic acid, total lactic acid bacteria (LAB), and water content of joruk
\end{abstract}

Keywords: Chemical, joruk, microbiological, physical

\section{INTRODUCTION}

Joruk is a fermented food that originated from Ogan Komering Ulu Timur, South Sumatra, Indonesia. Joruk is made from a mixture of Wader fish (Rasbora spp.), salt, palm sugar, and cooked rice that is fermented for one to two weeks. Joruk is similar to rusip and bekasam. Rusip is made without cooked rice and bekasam is made without palm sugars, besides that joruk and bekasam are made from freshwater fish, while rusip is made from saltwater fish (Puspita et al. 2017; Melia et al. 2019). Those ingredients are the success factor in the making of fermented fish products, so the development of joruk as one of fermented products requires proper process improvement. Anihouvi et al. (2006) and Kakati and Goswani et al. (2013) stated that fermented fish products are generally processed spontaneously and fermentation goes uncontrolled. This condition resulting in various quality of product and the product is susceptible to damage. Koesoemawardani et al. (2016) reported some of joruk were slimy which leads to spoilage. This condition indicating that the fermentation goes uncontrolled due to improper proportion usage of ingredients that can support the growth of the desired bacteria during fermentation such as lactic acid bacteria (LAB). According to Koesomawardani et al. (2016), Yuktika et al. (2017), and Koesoemawardani et al. (2019), the dominant microbes in fermented fish products are lactic acid bacteria.
The usage of salt is presumed to play an important role in controlling microbes during fermentation in the joruk's production, thus allowing the death of some bacteria that cannot stand in the presence of salt. Salt consists of $\mathrm{NaCl}$ will be dissociated to its constituent molecules, $\mathrm{Na}^{+}$and $\mathrm{Cl}^{-}$ . The $\mathrm{Na}^{+}$ion is needed by the lactic acid bacteria as one of the factors supporting its growth, while the $\mathrm{Cl}^{-}$ion binds the free water which lowering the availability of water in material, so the free water for microbes growth is decreased (Hadiwiyoto, 1993; Yuktika et al. 2017). Salt can select the unwanted bacteria, which is pathogenic and spoilage bacteria during fermentation, so the lactic acid bacteria are expected will dominate at the beginning of fermentation (Koesoemawardani et al. 2013). The activity of lactic acid bacteria which starts due to the decrease of water activity (Aw), water content, and acidic conditions, has become a critical point for inhibiting the growth of pathogen and spoilage bacteria. In addition, the salt used will also affect the characteristics of fermented fish products including physical, chemical, microbiology, and sensory properties (Kim et al. 2014; Fatimah et al. 2017). El Seikha et al. (2014) stated that the fish fermentation process that carried out without using salt will result in uncontrolled fermented products. Therefore, the aim of this study was to determine the effect of salt addition on the microbiological, physical, and chemical properties of joruk. 


\section{MATERIALS AND METHODS}

\section{Materials}

The main materials used in this study were freshwater fish locally called Wader (Rasbora spp.), coarse salt (Tani Makmur), palm sugar obtained from the traditional producer, and cooked rice (rice variety of IR 64).

\section{Preparation of materials}

The raw materials used are wader fish (whole fish), rice from IR 64 varieties, palm sugar, and salt. The amount of rice and palm sugar expressed as percent per weight of fish in each treatment. The amount of rice is $10 \%(\mathrm{w} / \mathrm{w})$ and palm sugar is $20 \%$ (w/w) used in the formulation of joruk. The first step was to prepare all materials and tools needed. Wader fish are washed with flowing water and then drained. Each sample (treatment) used $100 \mathrm{~g}$ of wader fish, and $10 \mathrm{~g}$ of rice. The palm sugar used in this research was in liquid form. The liquid palm sugar was prepared by heating the sugar and water $(3: 1)$ until it melts at $100{ }^{\circ} \mathrm{C}$ for 5 minutes, and then cooled down. The amount of palm sugar added is $20 \mathrm{ml}$. The salt is weighed per weight of fish according to the treatments, there are $5 \mathrm{~g}(5 \%), 10 \mathrm{~g} \mathrm{(10 \% ),}$ $15 \mathrm{~g}(15 \%), 20 \mathrm{~g}(20 \%), 25 \mathrm{~g}(25 \%)$, and $30 \mathrm{~g}(30 \%)$.

\section{Joruk production}

The production of joruk was carried out according to Koesoemawardani et al. (2019). The prepared wader fish were put in a $150 \mathrm{ml}$ of jar, and then the liquid palm sugar, rice, and salt were added. The mix then stirred until blended, but the rice kept to not completely crumbling (still intact). After all the ingredients are evenly mixed, then the jars were closed tightly by wrapping duct tape on the lid of the jar. Joruk was ready to be analyzed after being stored for seven days in an anaerobic state. Anaerobic condition was created by putting a small jar $(150 \mathrm{ml})$ per sample (treatment) into a large jar with the candle inside in lit condition. The jar is closed tightly by wrapping duct tape on the lid of the jar, and the anaerobic process started after the candle off.

\section{Observation}

\section{Measurement of $\mathrm{pH}$}

The $\mathrm{pH}$ samples were measured using a digital $\mathrm{pH}$-meter (Lovibond), after calibration using standard buffer solution of $\mathrm{pH} 4$ and $\mathrm{pH} 7$.

\section{Water content}

Determination of water content was carried out using gravimetric method following the AOAC (2005). Porcelain dishes were dried in the oven for 30 minutes, then cooled in a desiccator and weighed. A total of $5 \mathrm{~g}$ of the sample was weighed then put into a porcelain dish and dried in an oven at $105{ }^{\circ} \mathrm{C}$ for $3-5$ hours. After that, it is cooled down in a desiccator for 15 minutes then weighed. After obtaining the results of the first weighing, then the dish containing the sample was dried again for 30 minutes after which it was cooled in a desiccator for 15 minutes. The measured water content is expressed in percent $(\%)$ and calculated using the following formula:
Water content $(\%)=\frac{(W+W 2)-W 1}{W 2} \times 100 \%$

Where:

W : Weight of porcelain dish $(\mathrm{g})$

W1 : Weight of porcelain dish and sample after drying (g)

W2 : Weight of sample (g)

\section{Total lactic acid}

The total acid measurement was carried out following the AOAC (2005). A sample of 10 grams was crushed with a Waring blender, then put into a $250 \mathrm{ml}$ Erlenmeyer. Aquadest is added to the Erlenmeyer flask until it reaches the mark. The mixture is shaken out until homogeneous and then filtered. As much as $25 \mathrm{ml}$ of filtrate was added 23 drops of phenolphthalein indicator, then titrated with 0.1 $\mathrm{N} \mathrm{NaOH}$ solution to form a pink color. Every $\mathrm{ml}$ of $0.1 \mathrm{M}$ $\mathrm{NaOH}$ was considered equivalent to $90.08 \mathrm{mg}$ of lactic acid. Total lactic acid is calculated using the following formula:

\section{Total titratable acidity of lactic acid $(\mathrm{mg} / \mathrm{ml})=\underline{\mathrm{ml} \mathrm{NaOH} \times \mathrm{N} \mathrm{NaOH} \times \mathrm{M} . \mathrm{E}}$ Volume of sample used}

Where:

$\begin{array}{ll}\mathrm{ml} \mathrm{NaOH} & : \text { Volume of } \mathrm{NaOH} \text { used } \\ \mathrm{N} \mathrm{NaOH} & : \text { Molarity of } \mathrm{NaOH} \\ \text { M.E } & : \text { Equivalent factor }(90.08 \mathrm{mg})\end{array}$

Total volatile basic nitrogen (TVB-N)

The measurement of TVB-N was conducted following Gaseem (2019). Sample weighed $10 \mathrm{~g}$ and then was blended with $50 \mathrm{ml}$ of fresh tap water. The blender was washed with $250 \mathrm{ml}$ of fresh tap water into the distillation flask and 1-2 $\mathrm{g}$ of $\mathrm{MgO}$ was added to the mixture. TVB-N was released by boiling the mixture with magnesium oxide, which prevented volatile acids from distilling over into the boric acid. The distillate of volatile nitrogen was received in $25 \mathrm{ml}$ of boric acid $2.0 \%$ then titrated by $0.1 \mathrm{~N}$ sulfuric acid. The TVB-N value was expressed in $\mathrm{mg} \mathrm{N} / 100 \mathrm{~g}$ and calculated as follow:

TVB-N $(\mathrm{mg} \mathrm{N} / 100 \mathrm{~g})=$ Titration $(\mathrm{ml}$ of $0.1 \mathrm{~N}$ acid $) \times 14$

\section{Total lactic acid bacteria}

The measurement of total lactic acid bacteria was conducted following Khedid et al. (2009) and Karparvar et al. (2019). A sample of $1 \mathrm{~g}$ was put into a test tube containing $9 \mathrm{ml}$ of sterile $0.85 \%$ physiological salt as a diluent to obtain a sample suspension with a $10^{-1}$ dilution to a $10^{-10}$ dilution. A total of $1 \mathrm{ml}$ of sample each $10^{-8}, 10^{-9}$, and $10^{-10}$ dilutions were piped and put into each sterile petri dish, then poured $\pm 15 \mathrm{ml}$ of sterile MRS media agar (done in Duplo for each dilution) and shake evenly on the table or follow the pattern of number 8. After the agar media solidified, the plates were wrapped in paper and then incubated in upside-down position at $37{ }^{\circ} \mathrm{C} \pm 1{ }^{\circ} \mathrm{C}$ for $48 \pm$ 2 hours. The total number of lactic acid bacteria was counted (on a 30-300 colony scale) and expressed in cfu/g. The total lactic acid bacteria were calculated using the following formula:

Total lactic acid bacteria $=$ The number of colonies counted $\mathrm{x}$ (1/dilution factor) 


\section{Total microbial count}

The measurement of total microbial count follows the procedure of SNI 2333.3: 2015. A total of $1 \mathrm{~g}$ of sample was diluted with $9 \mathrm{ml}$ of sterilized physiological saline $(\mathrm{NaCl} 0.85 \%)$. This dilution is calculated as a $10^{-1}$ dilution. Further dilution is carried out by dissolving $1 \mathrm{ml}$ of the $10^{-1}$ dilution solution with $9 \mathrm{ml}$ of physiological saline and counting it as a $10^{-2}$ dilution and so on up to $10^{-12}$ dilutions. A total of $1 \mathrm{ml}$ of sample from each dilution $10^{-10}, 10^{-11}$, and $10^{-12}$ were taken and put into each sterile petri dish, then poured $\pm 15 \mathrm{ml}$ of sterile PCA (done in Duplo for each dilution) and shake evenly on the table or follow the pattern of number 8. After the agar media solidified, the plates were wrapped in paper and then incubated in upside-down position at $35{ }^{\circ} \mathrm{C} \pm 1{ }^{\circ} \mathrm{C}$ for $48 \pm 2$ hours. The total number of microbes was counted and expressed in cfu/g.

\section{Total mold}

The measurement of total mold follows the procedure of SNI 2332.7: 2015. A total of $1 \mathrm{~g}$ of sample was diluted with $9 \mathrm{ml}$ of sterilized physiological saline $(\mathrm{NaCl} 0.85 \%)$. This dilution is calculated as dilution $10^{1}$. Further dilution is carried out by dissolving $1 \mathrm{ml}$ of the $10^{-1}$ dilution solution with $9 \mathrm{ml}$ of physiological saline and counting it as a $10^{-2}$ dilution and so on up to $10^{-6}$ dilutions. A total of $1 \mathrm{ml}$ of sample from each dilution of $10^{-4}, 10^{-5}$, and $10^{-6}$, poured plates were made on Potato Dextrose Agar (PDA) medium. The incubation condition was at $25^{\circ} \mathrm{C}$ for $3-5$ days in a non-inverted position. The calculation was done using the Standard Plate Count (SPC) method, which is using a colony counter with the condition that the number of colonies per Petri dish is between 10-150 colonies, and there is no colony whose size covers more than half of the Petri dish.

\section{Data analysis}

This study used non-factorial Randomized Complete Block Design (RCBD) with four replications. The data analyzed by variance to determine whether there were differences among treatments. The similarity of data tested by the Tuckey test and following by the Smallest Real Difference (SRD) test at the level of 5\% with SPSS 18.0 for Windows. Treatments given to each replication are salt concentrations $(\mathrm{G})$ of $5 \%(\mathrm{G} 1), 10 \%(\mathrm{G} 2), 15 \%(\mathrm{G} 3), 20 \%$ (G4), 25\% (G5), and 30\% (G6) (w/w).

\section{RESULTS AND DISCUSSION}

\section{Total Lactic Acid Bacteria (LAB)}

The results of analysis of variance showed that salt concentration level had significant effect on total lactic acid bacteria of joruk during fermentation as shown in Table 1. The control treatment ( $0 \%$ of salt) was not carried out in this study because if the joruk was made without using salt it would result in uncontrolled fermentation products (unsuccessful). Total lactic acid bacteria in joruk ranged from 8.49-8.75 $\log \mathrm{cfu} / \mathrm{g}$ with the highest from 5\%-10\% salt concentration, 8.73-8.75 log cfu/g, and the lowest from $15 \%-30 \%$ salt concentration. The addition of high salt concentration decreases the number of lactic acid bacteria, this phenomenon was inversely proportional to the observed $\mathrm{pH}$ value. This occurs because the addition of high salt causes the growth inhibition of lactic acid bacteria, so the lactic acid bacteria did not optimally produce lactic acid. Salt consists of its constituent molecules, $\mathrm{Na}^{+}$and $\mathrm{Cl}^{-}$, where $\mathrm{Na}^{+}$is much needed by the lactic acid bacteria to support their growth factor, and $\mathrm{Cl}^{-}$ will binds the free water that causes the decrease of availability of water so that the free water for lactic acid bacteria's growth also reduced (Hadiwiyoto 1993; Yuktika et al. 2017). Due to the osmotic pressure of the solution, it causes plasmolysis which is followed by dehydration and then followed by the death of microorganisms. Salt also affects the water activity of the ingredients, so that it can control the growth of microorganisms. Therefore, the addition of high salt concentration causes lower water activity (Aw) value, results in the decreasing rate of lactic acid bacterial growth and increases the $\mathrm{pH}$ value (Aristyan, et al. 2014; Ahillah, et al. 2017). The growth of lactic acid bacteria was inhibited with salt concentration ranging from $15 \%$ to $30 \%$. In this study, lactic acid bacteria growth was stunted due to high salt concentration starting from $15 \%$ to $30 \%$. Total lactic acid bacteria results in this study were close to the results in Koesoemawardani et al. (2019), but they were lower than the results in Koesoemawardani et al. (2016) with $10.19 \log \mathrm{cfu} / \mathrm{g}$.

\section{Total microbes}

Total microbes in joruk with addition of different salt concentrations ranged from 13,39-13,18 log cfu/g. The result of analysis of variance showed that the addition of salt concentration had no significant effect on total microbes on joruk during fermentation (Table 1).

The same result also reported by Koesoemawardani et al. (2019) and Koesoemawardani et al. (2016). Furthermore, Desniar et al. (2012) reported the total microbes were not significantly different due to the total number of microbes counted are the microbes that involved in fermentation process, such as acid-forming bacteria (lactic, propionate, acetate), and several types of yeast and mold, while Widjajanti et al. (1996) reported that ingredient composition, including the salt used, also did not significantly affect the total number of microbes in bekasam because the available nutrients were sufficient for the growth of lactic acid bacteria, mold, and yeast, and their growth inhibitor product had not been formed.

Table 1. Microbiological properties of joruk

\begin{tabular}{lccc}
\hline \multirow{2}{*}{ Treatment } & Total LAB & Total microbes & Total mold \\
\cline { 2 - 4 } & & $(\mathbf{l o g} \mathbf{~ c f u} / \mathbf{g})$ & \\
\hline G1 $(5 \%)$ & $8.75 \pm 0.09^{\mathrm{a}}$ & $13.39 \pm 0.08$ & $4.32 \pm 0.03$ \\
G2 (10\%) & $8.73 \pm 0.14^{\mathrm{a}}$ & $13.17 \pm 0.17$ & $4.27 \pm 0.07$ \\
G3(15\%) & $8.57 \pm 0.10^{\mathrm{b}}$ & $13.24 \pm 0.19$ & $4.29 \pm 0.08$ \\
G4 (20\%) & $8.50 \pm 0.25^{\mathrm{b}}$ & $13.24 \pm 0.18$ & $4.36 \pm 0.06$ \\
G5 (25\%) & $8.49 \pm 0.15^{\mathrm{b}}$ & $13.20 \pm 0.14$ & $4.30 \pm 0.06$ \\
G6 (30\%) & $8.49 \pm 0.07^{\mathrm{b}}$ & $13.24 \pm 0.20$ & $4.27 \pm 0.08$ \\
\hline
\end{tabular}

Note: different letter in the same column indicated significant differences between treatments $(p<0,05)$ 
The fermentation type of joruk is spontaneous fermentation, while the dominating total microbes are lactic acid bacteria (Koesoemawardani et al. 2016; Yuktika et al. 2017; Koesoemawardani et al. 2019). According to Paludan-Müller et al. (2002), the addition of high salt concentration causes certain types of microorganisms that are resistant to high salt levels will grow, such as halophilic bacteria. The total microbes measured in this study were also affected by the number of lactic acid bacteria that grow. Meanwhile, lactic acid bacteria can still grow in the range of 5\% to 35\% salt added (Zuidar et al. 2016; Ahillah et al., 2017).

\section{Total mold}

Total mold of joruk with addition of different salt concentrations ranged from 4,37-4,27 log cfu/g. The result of analysis of variance showed that the addition of salt concentration had no significant effect on total mold of joruk during fermentation (Table 1). This is because the available nutrients are still sufficient for mold and yeast, and also their growth inhibitor product had not been formed, so the salt addition had no significant effect on the mold's growth (Widjajanti et al. 1996). The physiological properties of mold were still within the limits of their growth requirements. According to Querol and Fleet (2006) and Feldmann (2012), the physiological properties of molds are including the requirements of water, growth temperature, oxygen requirement, $\mathrm{pH}$, nutrients, and inhibitor compound. The observation results of water content in this study ranged from $44.74-61.78 \%$, while the water content requirements for biochemical reactions in molds ranged on $90 \%$, so it still supports mold growth. The optimum temperature for mold growth ranged from 25-30 ${ }^{\circ} \mathrm{C}$ or more, and in this study presumed that the storage condition still in room temperature $\left(25-30{ }^{\circ} \mathrm{C}\right)$. Mold grows well at $\mathrm{pH} 2-8.5$, while the $\mathrm{pH}$ in this study ranged from 4.65-6.11, so the mold still grows well in this condition. Meanwhile, the availability of oxygen still supports mold growth because the conditions of joruk's container in this study are facultatively anaerobic, so the molds still have oxygen to grow even in small amounts. Mold nutrients are in the form of carbon sources, nitrogen sources, energy sources, and growth factors (minerals and vitamins). The source of these nutrients in joruk was added in the same amount, while the treatment addition of salt was added on different concentration in this study only had an effect on lactic acid bacteria as the growth support. Therefore, the total mold in this research was not significantly different on each treatment. The inhibiting component was not present in joruk. According to Feldmann (2012), the inhibiting components of mold growth are including penicillium, clavasin, sorbic, propionic, and acetic acid. The growth of mold in this research was not different from Koesoemawardani et al. (2019).

\section{pH value}

The results of analysis of variance showed that the salt addition had significant effect on $\mathrm{pH}$ (Table 2). The $\mathrm{pH}$ value ranged from 4.65-6.11, while the $\mathrm{pH}$ value before fermentation on each treatment was not significantly different ranged from 6.53-6.68. The highest $\mathrm{pH}$ value of joruk ranged from 5.96-6.11 obtained in the treatment salt addition of $15 \%-30 \%$, while the lowest $\mathrm{pH}$ value of joruk is 4.65 from the treatment salt addition of $5 \%$. The increase in $\mathrm{pH}$ value was due to the addition of the salt concentration used. The higher salt concentration used can inhibit and decrease the growth of lactic acid bacteria. This will reduce the ability of lactic acid bacteria to produce lactic acid. Therefore, the high concentration of salt addition was not effective in reducing $\mathrm{pH}$ (Hadiyanti dan Wikandari, 2013; Kusmawarti et al., 2011; Thariq et al. 2014).

The increase in $\mathrm{pH}$ value could be occurred due to increased activity of decomposing bacteria in non-protein nitrogen compound that produces volatile bases. In addition, the increase in the addition of salt concentration results in the fermentation process was not occurred perfectly, because the fish meat has been damaged by salt so the ability of lactic acid bacteria in fermentation is reduced (Maliki et al. 2019). The $\mathrm{pH}$ value of joruk in previous study reached 5.43-5.78 (Koesoemawardani et al. 2016) and 4.92-5.26 (Koesoemawardani et al. 2019). The $\mathrm{pH}$ values in those studies are lower due to the low concentration of salt used, $10 \%$, while in this study use the highest concentration was $30 \%$. Gaseem (2019) stated that $\mathrm{pH}$ value of each fermented fish product has different value due to processing methods, variations in the ingredients used and the variation of amount (material formulation) added. The $\mathrm{pH}$ is one of the quality parameters of fermented fish products, even though there is no standard. Fermented fish product with $\mathrm{pH}$ value of 6.5 or higher, it is considered as a bad quality (Anihouvi et al. 2012). The quality of joruk in this study is still suitable for consumption because the $\mathrm{pH}$ value of joruk ranged from 4.65-6.11.

\section{Total lactic acid}

The results of analysis of variance showed that the addition of salt significantly affected the total lactic acid during fermentation (Table 2). The total amount of lactic acid ranges from 1.98-3.06\%. Salt addition supports the growth of lactic acid bacteria so that the fermentation process can run perfectly. Lactic acid bacteria will produce enzymes that hydrolyze complex carbohydrates into glucose and then will be converted into organic acids, especially lactic acid (Abdel-Rahman et al. 2013; Huang et al. 2020; Lestari et al., 2018; Rizal et al. 2020; Villalobos et al. 2020). However, if the salt added in higher concentration, the growth of lactic acid bacteria will be reduced and the production of lactic acid will be decreased. This result was in line with the total lactic acid bacteria observed in this study that the higher addition of salt can reduce the number of lactic acid bacteria. This is followed by a decrease in the formation of total lactic acid. The use of different proportions of ingredients in fermented fish products results in different total acids (Widjajanti et al. 1996). This could be causing the difference of total lactic acid produced in this study compared with Koesoemawardani et al. (2016) and Koesoemawardani et al. (2019), respectively, the total lactic acid formed was $0.71 \%$ and $6.21 \%-6.92 \%$. 
Table 2. Chemical properties of joruk

\begin{tabular}{lccc}
\hline Treatment & pH Value & $\begin{array}{c}\text { Total lactic } \\
\text { acid }(\%)\end{array}$ & $\begin{array}{c}\text { Water content } \\
(\%)\end{array}$ \\
\hline G1 (5\%) & $4.64 \pm 0.27^{\mathrm{c}}$ & $3.00 \pm 0.36^{\mathrm{d}}$ & $61.83 \pm 2.98^{\mathrm{a}}$ \\
G2 (10\%) & $5.84 \pm 0.24^{\mathrm{b}}$ & $2.97 \pm 0.18^{\mathrm{cd}}$ & $59.33 \pm 2.53^{\mathrm{ab}}$ \\
G3(15\%) & $5.96 \pm 0.09^{\mathrm{a}}$ & $2.88 \pm 0.00^{\mathrm{bc}}$ & $55.76 \pm 4.70^{\mathrm{abc}}$ \\
G4 (20\%) & $6.01 \pm 0.07^{\mathrm{a}}$ & $2.52 \pm 0.29^{\mathrm{ab}}$ & $51.49 \pm 5.20^{\mathrm{bcd}}$ \\
G5 (25\%) & $6.01 \pm 0.15^{\mathrm{a}}$ & $2.34 \pm 0.20^{\mathrm{a}}$ & $44.73 \pm 8.08^{\mathrm{d}}$ \\
G6 (30\%) & $6.11 \pm 0.08^{\mathrm{a}}$ & $1.98 \pm 0.20^{\mathrm{a}}$ & $49.90 \pm 8.76^{\mathrm{cd}}$ \\
\hline
\end{tabular}

Note: different letter in the same column indicated significant differences between treatments $(p<0,05)$

\section{Water content}

The results of analysis of variance showed that the addition of salt concentration had a significant effect on the water content of joruk during fermentation (Table 2). The water content of joruk produced in study ranged from 44.73 to $61.87 \%$. The higher addition of salt concentration causes a decrease in water content of joruk. Salt plays a role in attracting the water from fish body through an osmosis process, so the water content of joruk will decrease. The decrease of water content causes the water activity (Aw) value to decrease as the concentration of salt used increases. This result indicates that the higher salt concentration, the smaller water activity. Water activity affects microbial growth because it is a medium for growth and reproduction for bacteria (Aristyan et al. 2014; Majid, et al. 2014; Thariq et al. 2014; Fatimah et al. 2017; Puspita et al. 2019; Koeosemawardani et al. 2020). The water content of joruk in this study was similar to the result reported by Koesoemawardani et al. (2016) that is $61.04 \%$, while Koesoemawardani et al. (2019) reported joruk with a higher water content of $63.30 \%$. This happens due to difference in ingredient proportion added, especially the usage of salt concentrations.

\section{Best treatment selection}

Joruk is one of fermented products with potential to be functional food because of the presence of lactic acid bacteria that is good for gut health. In fermented products, low total mold is desirable (Indonesian National Standard of fermented fish, SNI 2716: 2016). Based on these requirements, the treatment that produces joruk with high total lactic acid bacteria and low total mold will be selected as the best treatment. In this study, the treatment with the highest total lactic acid bacteria result was found in joruk with $10 \%$ salt concentration (w/w).

In conclusion, based on the results from this study, it can be concluded that salt concentration had a significant effect on total $\mathrm{LAB}, \mathrm{pH}$ value, total lactic acid, and water content in joruk, however, it had no significant effect on total microbes and total mold in joruk. The addition of $10 \%$ salt produced the best joruk with the best microbiological, physical, and chemical properties as follows: total LAB of $8.75 \mathrm{log} \mathrm{cfu} / \mathrm{g}$, total microbes of $13.25 \mathrm{log} \mathrm{cfu} / \mathrm{g}$, and total mold of $4.27 \log \mathrm{cfu} / \mathrm{g}, \mathrm{pH}$ of 5.85 , total lactic acid of 2.97\%, Total Volatile Base (TVB) value of $153.05 \mathrm{mgN}$ $/ 100 \mathrm{~g}$, and water content of $59.33 \%$. Further research will be carried out regarding the investigation of amino acid, fatty acid, and volatile compounds from joruk.

\section{ACKNOWLEDGEMENTS}

We offer our gratitude to the Ministry of Research and Technology/National Research and Innovation Agency for their funding through Competitive Research 2019-2020

\section{REFERENCES}

Abdel-Rahman MA, Tashiro Y, Sonomoto K. 2013. Recent advances in lactic acid production by microbial fermentation processes. Biotechnol Adv 31: 877-902.

Ahillah N, Rusdanillah A, Afiana W, Sulistiani R, Mail RP. 2017. The influence of salt concentration on the fermentation of the wader fish (Rasbora lateristriata). Jurnal Bioedukasi 10: 12-17.

Anihouvi VB, Ayernor GS, Hounhouigan JD, Akyi-Dawsoin E. 2006. Quality characteristics of lanhouin: a traditional processed fermented fish product in the Republic of Benin. Afr J Food Agric Nutr Dev 6: $1-15$.

Anihouvi VB, Kindossi JM, Hounhouigan JD. 2012. Processing and quality characteristics of some major fermented fish products from Africa: A critical review. Intl Res J Biol Sci 1: 72-84.

AOAC. 2005. Official Methods of Analysis. Association of Official Analytical Chemists, Washington DC.

Aristyan I, Ibrahim R, Rianingsih L. 2014. The influence of different percentages of salt toward sensory and microbiological quality of shrimp paste. Jurnal Pengolahan dan Bioteknologi Hasil Perikanan 3: 60-66. [Indonesian]

Desniar, Setyaningsih I, Sumardi RS. 2012. Chemical and microbiological parameter changes and isolation of acid-producing bacteria during fermentation process of common carp (Cyprinus carpio) bekasam. Jurnal Pengolahan Hasil Perikanan Indonesia 15: 232-239. [Indonesian]

El Sheikha AF, Ray R, Montet D, Panda S and Worawattanamateekul W. 2014. African fermented fish products in scope of risks. Intl Food Res J 21: 425-432

Fatimah F, Pelealu JJ, Gugule S, Yempormase HV, Tallei TE. 2017. Quality evaluation of bakasang processed with variation of salt concentration, temperature and fermentation time. Pak J Biol Sci 20: 543-551. DOI: 10.3923/pjbs.2017.543.551

Gaseem, MA. 2019. Microbiological and chemical quality of a traditional salted-fermented fish (Hout-Kasef) product of Jazan Region, Saudi Arabia. Saudi J Biol Sci 26: 137-140.

Hadiwiyoto S. 1993. Teknologi Pengolahan Hasil Perikanan. Liberty, Yogyakarta.

Hadiyanti MR, Wikandari PR. 2013. The effect of salt concentration and the addition of lactic acid bacteria Lactobacillus plantarum B1765 as starter culture for the quality product of milkfish (Chanos chanos) bekasam. UNESA J Chemistry 2: 136-143.

Huang Z, Huang L, Xing G, Xu X, Tu C, Dong M. 2020. Effect of cofermentation with lactic acid bacteria and K. marxianus on physicochemical and sensory properties of goat milk. Foods 9: 299. DOI: 10.3390/foods9030299

Kakati BK, Goswami UC. 2013. Characterization of the traditional fermented fish product Shidol of Northeast India prepared from Puntius sophore and Setipinna phasa. Indian J Trad Knowl 12: 85-90.

Karparvar N, Safaei HG, Derakhshandeh A, Hemmati F, Mazloomi SM. 2019. Isolation and identification of lactic acid bacteria from a traditional fermented fish sauce (Mahyaveh) in Fars Province, Iran. Intl J Nutr Sci 4: 49-53. DOI:10.30476/IJNS.2019.81437.1005

Khedid K, Faid M, Mokhtari A, Soulaymani A, Zinedine A. 2009. Characterization of lactic acid bacteria isolated from the one humped camel milk produced in Morocco. Microbiol Res 164: 81-91. DOI: 10.1016/j.micres.2006.10.008

Kim BK, Lee HH, Jeng MH, Shim KB. 2012. Effect of fermentation temperature and salt concentration on the quality of jack mackerel (Trachurus japonicus) fish sauce. J Fish Mar Sci Educat 24: 755-762. DOI: 10.13000/JFMSE.2012.24.6.755 
Koesoemawardani D, Herdiana N, Suharyono, Hasly MZ, Ali M. 2019. The influence of cooked rice addition on the quality of joruk, an Indonesian freshwater fermented fish. Biosci Res 16: 3443-3448.

Koesoemawardani D, Hermawan YE, Herdiana N, Susilawati. 2020 Characteristic of rusip from trash fish. J Agric Prod Technol Industr 25: 120-128. DOI: http://dx.doi.org/10.23960/.v25i2.120-128

Koesoemawardani D, Marniza, Rizal S, Sella N. 2016. Addition of palm sugar in "Joruk" (fish fermentation). In: Prosiding Seminar Nasional Pengembangan Teknologi Pertanian. DOI: 10.25181/prosemnas.v0i0.477. [Indonesian]

Koesoemawardani D, Rizal S, Tauhid M. 2013. Microbiological and chemical changes of rusip during fermentation. agriTECH 33: 265 272. DOI: $10.22146 /$ agritech.9547

Kusmarwati A, Heruwati ES, Utami T, Rahayu ES. 2011. Effect of the addition of Pediococcus acidilactici F-11 as a starter culture on the quality of rusip. Jurnal Pascapanen dan Bioteknologi Kelautan dan Perikanan 6: 13-26.

Lestari S, Rinto, Huriyah SB. 2018. Increasing functionality of bekasam with Lactobacillus acidophilus as a starter. Indon Fish Processing J 21: 179-187. DOI: 10.17844/jphpi.v21i1.21596

Majid A, Tri WA, Laras R. 2014. The influence of different salt concentration on the sensory quality and volatile compounds of anchovy paste (Stolephorus sp.). Jurnal Pengolahan dan Bioteknologi Hasil Perikanan 3: 17-24. [Indonesian]

Maliki MK, Afrianto E, Liviawaty E, Rostini I. 2019. Effect of salt concentration with addition of lactic acid bacteria to preference levels of non-salty peda. Global Sci J 7: 388-393.

Melia S, Purwati E, Kurnia YF, Pratama DR. 2019. Antimicrobial potential of Pediococcus acidilactici from bekasam, fermentation of sepat rawa fish (Tricopodus trichopterus) from Banyuasin, South Sumatra, Indonesia. Biodiversitas 20: 3532-3538.

Paludan-Müller, Madsen M, Sophanodora P, Gram L, Møller PL. 2002. Fermentation and microflora of Plaa-Som a Thai fermented fish product prepared with different salt concentration. Intl J Food Microbiol 73: 61-70. DOI: 10.1016/S0168-1605(01)00688-2

Puspita DA, Agustini TW, Purnamayati L. 2019. The effect of different concentration of salt towards the glutamic acid in catfish Bakasang powder. Jurnal Teknologi Pangan 3: 110-115. DOI: 10.14710/jtp.3.1.110-115. [Indonesian]
Puspita ID, Wardani A, Puspitasari ROA, Nugraheni PS, Putra MMP, Pudjiraharti S, Ustadi. 2017. Occurrence of chitinolytic bacteria in shrimp rusip and measurement of their chitin-degrading enzyme activities. Biodiversitas 18: 1275-1281.

Querol A, Fleet. 2006. Yeasts in Food and Beverages. Springer, Brazil.

Rizal S, Suharyono, Nurainy F, Amelia JR. 2020. The effects of lowtemperature storage on the viability of Lactobacillus casei and the stability of antibacterial activity in green grass jelly synbiotic drinks. Biodiversitas 21: 3826-3831. DOI: 10.13057/biodiv/d210851

SNI 2332.3: 2006. Determination of total plate count (ALT) in fishery products. National Standardization Agency of Indonesia, Jakarta, Indonesia.

SNI 2332.7: 2015. Microbiological test method: Calculation of mold and yeast in fishery products. National Standardization Agency of Indonesia, Jakarta

SNI 2716: 2016. Shrimp paste. National Standardization Agency of Indonesia, Jakarta, Indonesia.

Thariq AS, Swastawati F, Surti T. 2014. The effect of different concentration of salt to the content of glutamic acid savoring flavor (umami) of mackerel fermented fish (Rastrelliger neglectus). Jurnal Pengolahan dan Bioteknologi Hasil Perikanan 3 (3): 104-111. [Indonesian]

Villalobos JAM, Zamora JM, Barboza N, Garbanzo CR, Usaga J, Solano MR, Schroedter L, Widdrat AO, Gómez JPL. 2020. Multi-product lactic acid bacteria fermentations: A review. Fermentation 6: 1-21. DOI: 10.3390/fermentation6010023

Widjajanti H, Arwinsyah, Munawar. 1996. Pengaruh komposisi bahan dan lama penyimpanan terhadap aspek mikrobiologi dan aspek biokimia dalam pembuatan bekasam. Jurnal Penelitian Sains 1: 11-15. DOI: 10.26554/jps.v0i1.222. [Indonesian]

Yuktika S, Sutiyanti E, Dhewi ES, Martika SD, Sa'diyah RD. 2017. The influence of salt concentration on the fermentation of shrimp. Bioedukasi 10: 18-22. DOI: 10.20961/bioedukasi-uns.v10i2.11568. [Indonesian]

Zuidar A, Rizal S, Widyastuti K. 2016. The effect of fish type and salt concentrations on bamboo shoots fish fermented. Jurnal Kelitbangan 4: 181-194. 